\title{
TELEVISION ADVERTISEMENTS MOTIVATE THE CONSUMERS OF MOBILE PHONES: AN OPINION FROM UNIVERSITY STUDENTS IN KARACHI, PAKISTAN
}

\author{
Muhammad Siddique* \\ Mariya Baig ${ }^{* *}$ \\ Muhammad Abu Zar Wajidi ${ }^{* * *}$
}

\begin{abstract}
Advertising is a tool by which the audience who may be the viewers, readers or listeners are communicated and convinced to buy or taking any action regarding the products, or getting information about the services provided. The TV advertisements influence the consumers' buying behaviour. The need of TV advertisement has increased with the fast growth of mobile phones industry in Pakistan. This paper investigates the relationship between independent variable of advertisement with dependent variables of consumer choice, consumer awareness, consumer perception, and consumer motivation by getting the responses of 250 respondents using questionnaires based on 5-point Likert scale from the graduating students of various faculties at University of Karachi. The main results of the study show a strong association between the independent and dependent variables. It is a fact that the brands which are advertised on TV are purchased more because people become emotionally attached with such brands or products. This study is very useful for producers, distributors, wholesalers and retailers as well engaged in mobile business in Pakistan.
\end{abstract}

Keywords: TV advertisement, consumer choice, consumer awareness, consumer perception

\section{Introduction}

Today, reputed organizations are investing a reasonable amount in different means of advertisement such as radio, magazines, newspapers, television etc. Mobile industry has grown vastly for the last decade and almost in every city of Pakistan there are a large number of mobile shops and even mobile malls are also available for fulfilling the requirements of the general public and contributing a reasonable amount every year in the GDP of Pakistan. Mobile companies promote their products mostly on television for making the consumers' awareness. Due to this, most of the customers /consumers get their better choice. TV ads motivate general public and what they perceive, they decide accordingly.

\footnotetext{
"Muhammad Siddique, Assistant Professor, Pakistan Navy School of Logistics, PNS Karsaz, Karachi

** Mariya Baig, Research Scholar, Department of Public Administration, University of Karachi

*** Muhammad Abu Zar Wajidi, Ph.D. Professor (Meritorious), Director, Institute of Health \& Business

Management (IOHBM), Jinnah Sindh Medical University, Karachi
} 
Mobile phones have become the basic need of individuals' communication across the world in the past 15 years, there is a little consumer research on this area in Pakistan although it is a very helping tool for understanding and making the right marketing and selling plans for the consumer market. ${ }^{1}$ Pakistan mobile phone industry has grown very rapidly for the last more than one and half decade and TV advertisements play the main role in its growth. Therefore, most of the customers take purchasing decisions after watching TV advertisements because in this way they are motivated for purchasing decisions. TV ads provide complete information to the customers regarding their required brands of mobile phones and also save their searching time. Hence, customers get awareness for any available brands of Nokia, Samsung, Sony Ericson, Apple, BlackBerry, Q Mobile, China Mobiles, etc. in the market and in this way they can choose their brands at affordable price without much difficulties. ${ }^{2}$

Therefore, present study is an effort to evaluate the effectiveness of TV advertisements and their effect on consumers' buying behaviour especially that of mobile phones in Pakistan. It proves that TV advertisements accelerate the emotions and feelings of customers for taking purchasing decision for branded goods like mobile phone sets. This study is quantitative in nature. The study covers of the problem statement, research question, and objective of study, scope of study, significance of study, beneficiary of study, research limitations, and literature review that consist of conceptualization of conceptual framework and research hypotheses have been discussed. Afterward, a discussion of the research methodology is given that is covering the population of research, sampling techniques and sample size, data collection techniques and instruments used in this research and then presentation of the results is given. Finally, the conclusion and contribution and directions for further possible research has been discussed.

\section{Literature Review}

The literature review is considered the most necessary part of a research because this portion indicates that how much work is done before this by different people in the same field. It provides the base and background to new researchers. It is clearly indicated in the literature review that the buying process of consumers is significantly affected with watching of TV advertising in their daily life. Basically the prime purpose of an advertiser is to create the awareness about the available products and services in the market and to motivate and convince them for purchasing such products because in such advertising mostly benefits of the consumers are told in such an effective and persuasive way that every one after watching TV ads reacts emotionally and decision immediately. The advertising companies spend the huge amount on individuals' motivation and interest and for getting the customers' positive response and they can understand the users' requirements for future production. The basic purpose of this study is to find out

\footnotetext{
${ }^{1}$ Saeed, R., Zameer, H., \& Abbas, R. Mobile Phone buying behavior of consumers; A comparative study of Rural and Urban consumers in Pakistan. Global Journal of Management and Business Research, 12(6) (USA: Global Journals Inc., 2012)

${ }^{2}$ Arshad, H. M., Noor, M., Noor, N., Ahmad, W., \& Javed, S. Impact of Effective Advertising on Consumer Buying Behaviour: A Study of Mobile Phone Purchases in Pakistan. Journal of Basic Applied Sciences Research, 4(3), (Cairo, Egypt: Text Road Publication, 2014) 224-231.
} 
the influence of TV advertisings of the mobile companies on the buying behavior of consumers. The researchers determined it that some TV advertisements are so catching that they must put their impact on consumers buying decisions. The results got from this study evidently point out that there is a significant relationship between the TV advertisements and independent variables such as consumer choice, consumer awareness, consumer perception and consumer motivation. ${ }^{3}$ It is further explored by Karim, et.al., ${ }^{4}$ that advertising acts as a tool of communication that is a very important promotional activity. In other words, it is a fundamental promotional service to the success of every organization in meeting of its sales targets. For a long time, TV advertising are effective and faster way of communication. In Pakistan, the mobile phone industry is one of the most dynamic and well-known areas of business. Mobile phone sets are used by cellular companies who are playing a vital role in economic development of Pakistan. This sector has made a remarkable progress across the world in the last 15 years as well in Pakistan. That is why, the investors and cellular companies expect a brighter future and are paying more attention and spending more money towards the growth and development and expansion of coverage area and betterment and improving of services as well as making improvement in infrastructure.

Hassan pointed out that television advertisements influence positively to the customers who take purchase decision after watch such advertisements. ${ }^{5}$ The research disclosed that better-informed customers are getting information regularly through TV advertisements. Products of the best quality, fully featured and at the reasonable prices are needed to satisfy the consumers. Due to TV advertisements, customers may get their required products from the market at affordable prices. ${ }^{6}$ It is further noted that telecommunication sector in Pakistan has registered a strong and healthy growth in the beginning of 2002 and during the last decade, a huge growth has been recorded in sector of mobile business. Saleem and Abideen ${ }^{7}$ highlighted that TV advertisement is a method of conveying the message to the target audience to convince to purchase some products or some sort of services provided by a company. They further explained that an advertiser's basic objective is to inspire the potential customers and to motivate them for purchasing and influence their buying behaviour. For getting positive response from the target customers they spend a lot of money on TV advertisements. That is why, it is said that TV ads play a positive role in creating the complete product (mobile phone) awareness to the consumers for choosing their required mobile sets available in the market. The consumers buy their required sets and if they find them as per their perception, they recommend such products (mobiles) to their friends and relatives and motivate and help them in their decision making. In Pakistan, the growth of mobile industry has put a very positive

\footnotetext{
${ }^{3}$ Karim, L.N., Shehzad, M., Arshad, S. Effects of TV Advertising of Cellular Companies on User's Behavior. International Journal of Humanities and Social Science, 7(3) (USA: Center for Promoting Ideas , 2017)

${ }^{4}$ Ibid.

${ }^{5}$ Hassan, A. Effects of TV Advertisement on Consumer Buying Behaviour: A Comparative Study of RuralUrban and Male-Female Consumers. International Journal of Innovation and Applied Studies, 11(3), (Haryana, India: ISSR Journal Department, INNOSPACE INTERNATIONAL, 2015):608.

${ }^{6}$ Bhutto, R. A., \& Maqsood, A. Customer Services: A Case Study of Cellular Phone Companies in Pakistan, Journal of Independent Studies and Research, 5 (1) (Karachi, Pakistan: SZABIST, 2007):p 19-23

${ }^{7}$ Saleem, S., \& Abideen, Z. Effective advertising and its influence on consumer buying behavior. European Journal of Business and Management, 3(3), (Online: IISTE, 2011):55-67
} 
impact on the economic indicators such as a reasonable increase in the number of employees in this sector that increased the employment wages, tax revenue, and gross domestic product (GDP) cited by Chowdhury, et.al. ${ }^{8}$

\section{Research Background}

It was noted that by the end of 2016 a total of 4.8 billion subscribers had covered two thirds of the world's population and it is expected that by 2020 about three quarters of the world's population or 5.7 billion people will include themselves in the list of mobile subscribers. ${ }^{9}$ Pakistan had gown very rapidly in mobile sector since last one and half decade. According to Okeleke, et al., ${ }^{10}$ Pakistan is included in fast-growing Asian markets in the mobile sector. It is included in top 10 countries by projected new subscribers and it is expected that by 2020 it will have 17 million new unique mobile subscribers. Mobile companies advertise their products on Pakistan Television and other channels as well and people get information regarding their required products.

\section{Problem Statement}

Reading habits are decreasing in the society day by day. Mostly people remain engaged in solving their financial and economic problems. In this situation, the effective promotional tool for advertisement is television. Those companies who advertise their products on television regularly are more succeeded in meeting their sales targets because a large number of consumers are watching television in their free time. All mobile companies can achieve their sales targets easily by advertising their products on television regularly.

\section{Research Question}

Would television ads become the reason for rising the sales volume of mobile phone business?

\section{Objectives of the Study}

The objective of study is to find out the influence of television ads on the sales of mobile phone business because now-a-days people have become much engaged and reading habits have become slow in the society and everyone is seeking the fast and easy way for finding one's required things available in the market at the affordable prices and TV advertising are the best sources for this purpose.

\footnotetext{
${ }^{8}$ Chowdhury, H. K., Parvin, N., Weitenberner, C., \& Becker, M. Consumer attitude toward mobile advertising in an emerging market: An empirical study. International Journal of Mobile Marketing, 1(2) (New York City, USA: MMA=Mobile Marketing Association, GLOBAL, 2006).

${ }^{9}$ Okeleke, K., Rogers, M. \& Pedros, X. (2017, February 27), The Mobile Economy 2017, GSMA Intelligence. Retrieved from:

https://www.gsmaintelligence.com/research/?file=9e927fd6896724e7b26f33f61db5b9d5\&download.

${ }^{10}$ Okeleke, K., Rogers, M. \& Pedros, X. (2017, February 27), The Mobile Economy 2017, GSMA Intelligence. Retrieved from:

https://www.gsmaintelligence.com/research/?file=9e927fd6896724e7b26f33f61db5b9d5\&download
} 


\section{Scope of the Study}

The scope of the study is to focus on the consumers' choice, awareness, perception and motivation level that are directly linked with the television advertising and most of the consumers take their buying decisions after watching such repeated ads on television.

\section{Significance of the Study}

The findings presented in this research could be used by all the mobile sellers for increasing their sales by regular advertising their products on television.

\section{Beneficiary of the Study}

The research work will definitely be beneficial for the producers, distributors, wholesalers, and retailers. It will also help the policy makers and the organization who wants to introduce the new product/brand in the new/existing markets.

\section{Research Limitations}

In this study researchers have tried to collect information from different levels of university students to find out the effect of television on consumers' buying decision. The researchers highly depended on respondents' answers. It is observed that respondents or participants are never hundred per cent honest. There may be the chances of false or wrong answers.

\section{Conceptual framework:}

Based on the study of relevant articles, the researcher has framed the literature review as under:

Fig. 1: Conceptual Framework

\section{$\underline{\text { Dependent Variables }} \quad \underline{\text { Independent Variable }}$}

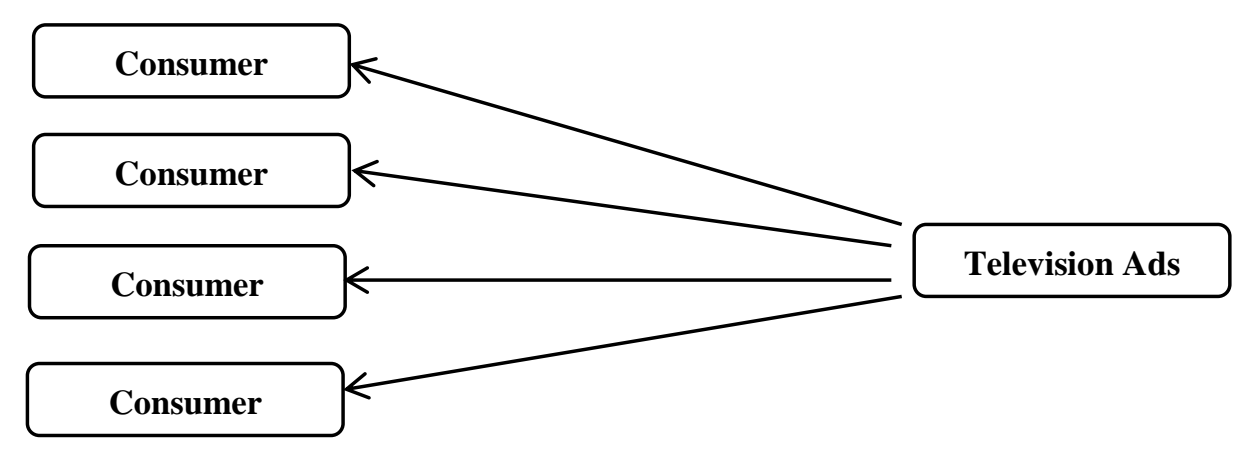

(Source: Developed by the researcher) 
The attempt is made to define the advertising and present the summaries of different researches. A conceptual frame work is developed with the help of prior researches. The definitions and summaries are as follows:

Advertising: It is a promotion device that is used by the organizations to promote their goods and services widely. The ultimate aim of effective advertising is to increase the sales of goods and services. ${ }^{11}$ Advertising has an extraordinary and dynamic effect on buying behavior of shoppers. ${ }^{12}$

\section{Television Ads \& Consumer Choice:}

$\mathrm{Kahn}^{13}$ explained that after watching repeated TV Ads consumers able to choose their products and now they can easily take purchasing decisions for their required products available in the market. According to Ashaduzzaman and Rehman, ${ }^{14}$ the T.V. advertisements stimulate consumers in choosing a new product that was introduced in the market recently. It was further stated that Television Ads convince the consumers for choosing consumers' products during their routine shopping. Chakrabortty, et al., ${ }^{15}$ cited that the role of TV ads in consumer's choice is unavoidable.

\section{Hypothesis-1}

$\mathbf{H}_{01}$ : Television Ads and consumer choice are not associated with each other.

\section{Television Ads \& Consumer Awareness:}

Consumer awareness means that the consumers get awareness about the attributes of the available products in the market. In other words, it is obvious that TV Advertisements are source of information regarding the consumers" markets where a variety of consumers, products are sold at the affordable prices. ${ }^{16}$ A television advertisement influences the consumers' buying behavior and also helps them in selection of their particular. ${ }^{17}$

\section{Hypothesis-2}

$\mathbf{H}_{\mathbf{0 2}}$ : Television Ads and consumer awareness are not associated with each other.

${ }^{11}$ Rossiter, J. R., \& Percy, L. Advertising and promotion management. (McGraw-Hill Book Company, 1987).

${ }^{12}$ Arshad, H. M., Noor, M., Noor, N., Ahmad, W., \& Javed, S. Impact of Effective Advertising on Consumer Buying Behaviour: A Study of Mobile Phone Purchases in Pakistan. Journal of Basic Applied Sciences Research, 4(3), (Cairo, Egypt: Text Road Publication, 2014):224-231.

${ }^{13}$ Kahn, E. B. (2014). Glossary, Knowledge Wharton High School, Wharton University Pennsylvania, retrieved on December 22, 2014 and available at http://kwhs. wharton.upenn.edu/term/consumer-choice/ (accessed on 20 Feb.2018)

${ }^{14}$ Ashaduzzaman, M., \& Asif-Ur-Rahman, S. M. Impact of Television Advertisements on buying pattern of Women in Dhaka City. European Journal of Business and Management, 3(3), (Online: IISTE, 2011):16-27.

${ }^{15}$ Chakrabortty, R. K., Hossain, M. M., Farhad, M., Azad, H., \& Islam, M. J. Analyzing the Effects of Sales Promotion and Advertising on consumer's Purchase Behaviour, World Journal of Social Sciences 3(4), (Australia: World Business Institute, 2013):183-194

${ }^{16}$ Barroso, A. \& Llobet, G. Advertising and Consumer Awareness of New, Differentiated Products, CEMFI Working Paper No.1104, (2011)

${ }^{17}$ Sawant, R. P. (2012). Impact of Advertising on Brand Awareness and Consumer Preference (With Special Reference to Men's Wear). IOSR Journal of Business and Management, 5(6), (India: IOSR, 2012):54-61. 


\section{Television Ads \& Consumer Perception:}

Consumer perception means how a consumer understand about a particular product or brand.$^{18}$ For elaborating the concept of consumer perception, Azeem and $\mathrm{Haq}^{19}$ cited that television ads make consumer perception more strong about a particular product or a brand because such ads are developed purposely. According to Malik et.al., ${ }^{20} \mathrm{TV}$ ads develop consumer perception and when they make some concepts regarding the available product for its price, and quality they are persuaded for buying such products at their convenience as early as possible.

\section{Hypothesis-3}

$\mathbf{H}_{03}$ : Television Ads and consumer perception are not associated with each other.

\section{Television Ads \& Consumer Motivation:}

According to Topaloglu, ${ }^{21}$ by TV ads consumers intend to purchase a certain product. It accelerate the feelings by which a consumer agrees to purchase products and services as per his or her desire. Jaworski, et.al. ${ }^{22}$ expressed that when consumers watch TV ads about a particular product or brand, they are motivated for purchasing the same. Although, companies spend a lot of money on such ads but on the other hand the motivated customers now play the role of the company's ambassadors and due to the words of mouth they promote the products continuously. TV advertisements motivate the consumers in such a way that they become ready for purchasing the advertised products that increase the sales of these companies very rapidly and help in meeting their selling targets. $^{23}$

\section{Hypothesis-4}

$\mathbf{H}_{\mathbf{0 4}}$ : Television Ads and consumer motivation are not associated with each other.

\section{Research Methodology}

Population: The graduating students of University of Karachi were taken as the population of this study.

\footnotetext{
${ }^{18}$ Honkaniemi, M. Consumer's s product perceptions and the impact of advertising on product images: case Mieleinen honey product, (2014).

${ }^{19}$ Azeem, A., \& Haq, Z. U. Perception towards Internet advertising: A study with reference to three different demographic groups. Global Business and Management Research: An International Journal, 4(1), (USA: Universal Publisher, 2012):28-45.

${ }^{20}$ Malik, M. E., Ghafoor, M. M., \& Iqbal, H. K. The Impact of Advertisement and Consumer Perception on Consumer Buying Behavior. International Review of Social Sciences \& Humanities, 6(2) (India: IRSSH Research Group, 2014).

${ }^{21}$ Topaloğlu, G. Consumer motivation and concern factors for online shopping in turkey, Asian Academy of Management Journal, 17(2) (Malaysia: AAM \& Penerbit Universiti Sains Malaysia, 2012):1-19

${ }^{22}$ MacInnis, D. J., Moorman, C., \& Jaworski, B. J. (1991). Enhancing and measuring consumers' motivation, opportunity, and ability to process brand information from ads. The Journal of Marketing, 55(4) (USA:

American Marketing Association, 1991), 32-53.

${ }^{23}$ Ashaduzzaman, M., et.al. Op.cit.
} 
Sampling Technique: Convenient sampling method (non-probability sampling method) has been used as sampling technique.

Sample Size: The data of 250 respondents were taken as sample size for this study in which respondents of the study were requested to complete the structured questionnaire on voluntary basis.

Data Collection Technique and Instrument: The data was collected through questionnaires developed on five-options (5-points) Likert scale. The questionnaires were distributed among the respondents (students of different levels) in different faculties of university of Karachi personally by the researchers. The data were taken from both male and female students of University of Karachi from different faculties. The majority of respondents were male students. Average age of the respondents was calculated as 34.28 years, all of the respondents were university students. More than half of the respondents were the students of master degree programs. $28.8 \%$ of the respondents were the students of M.Phil. program, $14.4 \%$ students were of graduate programs and $4.8 \%$ were of Ph.D. students. It took 20 days for collection of data from respondents and then data was very carefully fed into the Statistical Package for Social Sciences (IBM SPSS Statistics 19) version 19.0 for further analysis and as per these results the process of evaluation has been completed.

\section{Constructs of Study}

The consumer choice is one of the constructs of the study. It emphasizes that consumers have better and more suitable choice if a product is advertised. In other words, consumers have different options to make decision.

The other construct is consumer awareness. It is stated that advertising is a tool that aware the people about the consumer products available in the market.

Another construct of study is consumer perception. Advertising is a process that helps in making the perception of consumers more clear for a product. It provides the guidelines for recognition of a product.

The last construct is consumer motivation. When a product is advertised on television, people are motivated and they decide to purchase such products at their convenience. Therefore, it is clear that TV advertisements motivate the consumers for buying more. 


\section{Measures and Scales}

Table 1: Independent and dependent variables with No of questions

\begin{tabular}{|l|l|l|}
\hline Measures & Authors & $\begin{array}{l}\text { No of } \\
\text { Items }\end{array}$ \\
\hline TV Advertisements & (Rossiter \& Percy, 1987). (Arshand, et al., 2015). & 3 \\
\hline Consumer Choice & (Ashaduzzaman and Rehman, 2011) & 5 \\
\hline Consumer Awareness & (Barroso, 2008), (Sarwand, 2012). & 5 \\
\hline Consumer Perception & Azeemand Haq (2012, Malik et al., (2014) & 5 \\
\hline Consumer Motivation & $\begin{array}{l}\text { (Jaworski, et al., 1991), (Ashaduzzaman and } \\
\text { Rehman, 2011). }\end{array}$ & 5 \\
\hline Source: Developed by the researcher
\end{tabular}

The questionnaire had two parts. The first part collected the respondent's demographic data, and the second part of it was contained the purpose of the study. In the second part the subjects were asked to respond to twenty three questions on a 5-point Likert scale.

\section{Results}

Average age of the respondents was calculated as 34.28 years. The majority of respondents were male students. More than hfalf of the respondents were the students of master degree programs. $28.8 \%$ of the respondents were the students of M.Phil. Program, $14.4 \%$ students were of graduate programs and $4.8 \%$ were of Ph.D. students.

Instrument of Reliability: For checking the internal reliability of the instrument, Cronbach's alpha was calculated. The value of Cronbach's Alpha was 0.765 i.e. greater than 0.7. It is suggested the accepted edge of reliability should be at least 0.70 . It shows that our instrument is reliable.

\section{Data Analysis}

The data presented in table 2 as shown below indicate that the correlation matrix for the direction of relationship between the variables. The correlation analysis shows that Consumer Choice has a highest positive correlation value $(r=0.308)$. The Consumer Perception has the value $(\mathrm{r}=0.259)$ and it exerts considerable impact on TV Advertisements. The Consumer Awareness and Motivation ( $\mathrm{r}=0.248)$ also perfectly positively associated with TV Advertisements.

The testing of hypotheses developed earlier revealed the following results in which first and the third hypotheses about the association between TV Advertisements and consumers choice, and TV Advertisements and consumers perception are rejected 
because sufficient evidence were not found to accept the null hypotheses and the p-values were calculated as 0.000 i.e. $\mathrm{p}<0.05$. The second and the fourth hypotheses were also rejected because the $\mathrm{p}$-values were calculated both as 0.007 i.e. $\mathrm{p}<0.05$.

Table 2: TV Advertisement's Effect on Consumer Buying Behavior

\begin{tabular}{|l|c|c|}
\hline TV Advertisement v/s & Correlation & P-Value \\
\hline Consumer Choice & 0.318 & 0.000 \\
\hline Consumer Awareness & 0.268 & 0.007 \\
\hline Consumer Perception & 0.236 & 0.000 \\
\hline Consumer Motivation & 0.318 & 0.007 \\
\hline
\end{tabular}

Source: Developed by the researcher

\begin{tabular}{|c|c|c|c|c|c|c|c|}
\hline & \multicolumn{5}{|c|}{ TV Advertisement } & \multirow[b]{2}{*}{ Total } \\
\hline & & \begin{tabular}{|l|} 
Strongly \\
Disagree
\end{tabular} & Disagree & Neutral & Agree & $\begin{array}{l}\text { Strongly } \\
\text { Agree }\end{array}$ & \\
\hline \multirow[t]{5}{*}{\begin{tabular}{|l|} 
Consumer \\
Choice
\end{tabular}} & $\begin{array}{l}\text { Strongly } \\
\text { Disagree }\end{array}$ & 0 & 0 & 0 & 0 & 1 & 1 \\
\hline & Disagree & 0 & 1 & 1 & 4 & 0 & 6 \\
\hline & Neutral & 2 & 3 & 4 & 11 & 6 & 26 \\
\hline & Agree & 1 & 2 & 10 & 89 & 54 & 156 \\
\hline & Strongly Agree & 1 & 0 & 0 & 23 & 37 & 61 \\
\hline Total & & 4 & 6 & 15 & 127 & 98 & 250 \\
\hline \multirow[t]{5}{*}{$\begin{array}{l}\text { Consumer } \\
\text { Awareness }\end{array}$} & $\begin{array}{l}\text { Strongly } \\
\text { Disagree }\end{array}$ & 0 & 0 & 0 & 0 & 1 & 1 \\
\hline & Disagree & 0 & 2 & 1 & 11 & 0 & 14 \\
\hline & Neutral & 1 & 2 & 5 & 21 & 8 & 37 \\
\hline & Agree & 2 & 2 & 8 & 71 & 60 & 143 \\
\hline & Strongly Agree & 1 & 0 & 1 & 24 & 29 & 55 \\
\hline Total & & 4 & 6 & 15 & 127 & 98 & 250 \\
\hline \multirow[t]{5}{*}{$\begin{array}{l}\text { Consumer } \\
\text { Perception }\end{array}$} & $\begin{array}{l}\text { Strongly } \\
\text { Disagree }\end{array}$ & 0 & 1 & 0 & 0 & 1 & 2 \\
\hline & Disagree & 0 & 1 & 0 & 6 & 0 & 7 \\
\hline & Neutral & 2 & 2 & 6 & 16 & 12 & 38 \\
\hline & Agree & 2 & 1 & 7 & 85 & 55 & 150 \\
\hline & Strongly Agree & 0 & 1 & 2 & 20 & 30 & 53 \\
\hline Total & & 4 & 6 & 15 & 127 & 98 & 250 \\
\hline \multirow[t]{5}{*}{$\begin{array}{l}\text { Consumer } \\
\text { Motivation }\end{array}$} & \begin{tabular}{|l} 
Strongly \\
Disagree
\end{tabular} & 0 & 2 & 1 & 3 & 1 & 7 \\
\hline & Disagree & 1 & 2 & 3 & 23 & 9 & 38 \\
\hline & Neutral & 2 & 2 & 6 & 69 & 45 & 124 \\
\hline & Agree & 1 & 0 & 5 & 32 & 42 & 80 \\
\hline & Strongly Agree & 0 & 0 & 0 & 0 & 1 & 1 \\
\hline Total & & 4 & 6 & 15 & 127 & 98 & 250 \\
\hline
\end{tabular}

Source: Generated by the SPSS 
Table 3: Correlational Matrix

\begin{tabular}{|c|c|c|c|c|c|c|}
\hline \multicolumn{7}{|l|}{ Correlations } \\
\hline & & TV Ads & $\begin{array}{l}\text { Consumer } \\
\text { Choice }\end{array}$ & $\begin{array}{l}\text { Consumer } \\
\text { Awareness }\end{array}$ & $\begin{array}{l}\text { Consumer } \\
\text { Perception }\end{array}$ & $\begin{array}{l}\text { Consumer } \\
\text { Motivation }\end{array}$ \\
\hline \multirow{5}{*}{\begin{tabular}{|l|} 
Pearson \\
Correlation \\
\end{tabular}} & TV Ads & 1.000 & .308 & .248 & .259 & .248 \\
\hline & $\begin{array}{l}\text { Consumer } \\
\text { Choice }\end{array}$ & .308 & 1.000 & .338 & .427 & .415 \\
\hline & $\begin{array}{l}\text { Consumer } \\
\text { Awareness }\end{array}$ & .248 & .338 & 1.000 & .415 & .255 \\
\hline & $\begin{array}{l}\text { Consumer } \\
\text { Perception }\end{array}$ & .259 & .427 & .415 & 1.000 & .280 \\
\hline & $\begin{array}{l}\text { Consumer } \\
\text { Motivation }\end{array}$ & .248 & .415 & .255 & .280 & 1.000 \\
\hline \multirow[t]{5}{*}{ Sig. (1-tailed) } & TV Ads & . & .000 & .000 & .000 & .000 \\
\hline & $\begin{array}{l}\text { Consumer } \\
\text { Choice }\end{array}$ & .000 & . & .000 & .000 & .000 \\
\hline & $\begin{array}{l}\text { Consumer } \\
\text { Awareness }\end{array}$ & .000 & .000 & . & .000 & .000 \\
\hline & $\begin{array}{l}\text { Consumer } \\
\text { Perception }\end{array}$ & .000 & .000 & .000 & 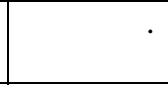 & .000 \\
\hline & $\begin{array}{l}\text { Consumer } \\
\text { Motivation }\end{array}$ & .000 & .000 & .000 & .000 & \\
\hline
\end{tabular}

Source: Generated by the SPSS

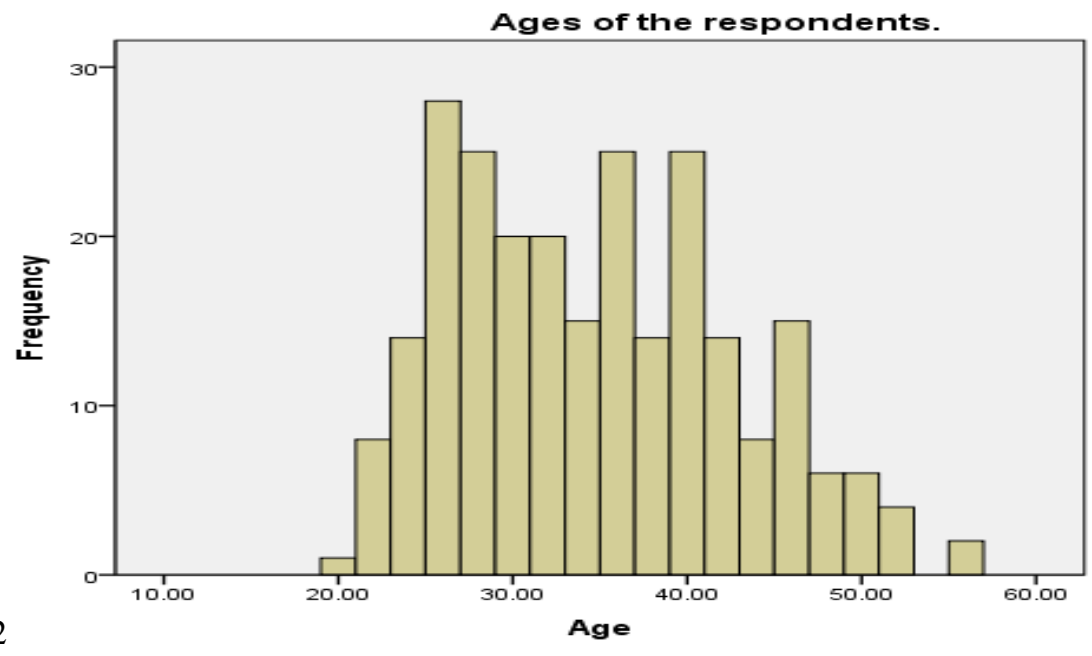

Fig.2

Source: Generated by the SPSS 
Fig. 3

Qualification of respondents

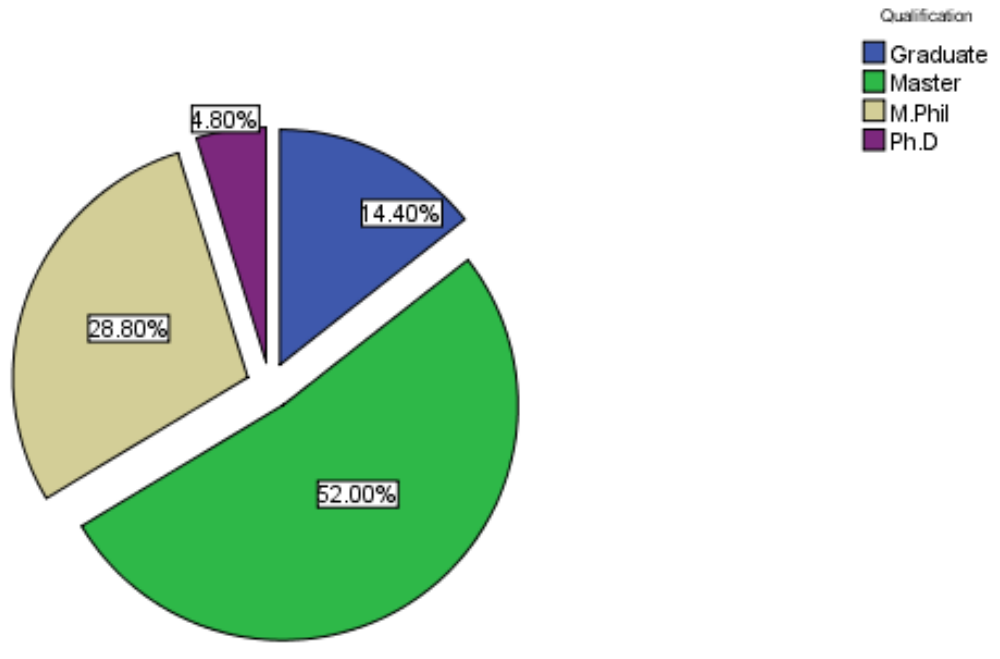

Source: Generated by the SPSS

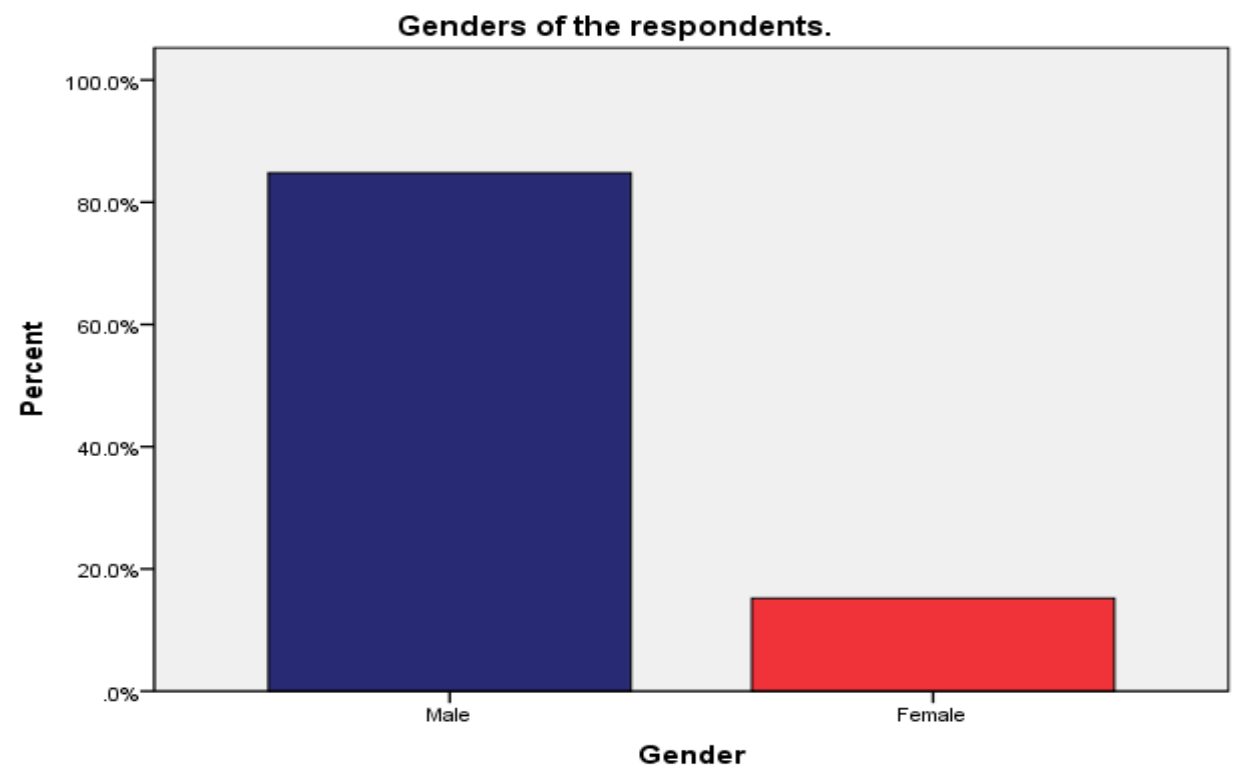

Fig. 4

Source: Generated by the SPSS 


\section{Conclusions and Discussion}

The results of this research study show that there exists a strong association between television advertisements and consumer choice, television advertisements and consumer awareness, television advertisements and consumer perception and television advertisements and consumer motivation because all the Null hypotheses were rejected and all Alternate hypotheses were accepted. Therefore, it is established through this research that television advertisements have direct impact on consumer choice, consumer awareness, consumer perception and consumer motivation that is why if mobile companies advertise their products on television regularly, the sales volume of these companies may be increased as per their set targets.

As we see the Pearson correlation coefficient was not too strong in this study, none of its value is greater than 0.427 . In addition, since the population of the study is university student so we can say these responses and behavior are the responses of well-educated peoples only, that might be different in non-educated or less educated people.

\section{Contributions and Directions for Further Study}

Firstly, this study identifies the consumer behavior and also its factors that mostly depend on the TV advertisement. This study also reveals the positive relationship between TV advertisement and all four variables (Consumer Choice, Consumer Awareness, Consumer Perception, and Consumer Motivation).

This research is conducted for finding the influence of television advertisements on the sales of mobile phone business in Karachi, Pakistan but it is not covering all the promotional tools of a business, it is advised to future researcher(s) that they must research on this field by using other promotion tools of marketing such as direct marketing, publicity, sales promotion or public relation, etc. for elaborating this concept more. It is further added that there is a gray area to conduct research regarding personality characteristics of consumers and to find out the impact of such characteristics on the consumer buying behavior in Pakistan. In further research, the true association of personality characteristics of the consumers and psychological factors that speed up the buying behavior of consumers will certainly help practitioners in improving their marketing strategies for meeting their selling targets.

\section{References}

Arshad, H. M., Noor, M., Noor, N., Ahmad, W., \& Javed, S. (2015). Impact of Effective Advertising on Consumer Buying Behaviour: A Study of Mobile Phone Purchases in Pakistan. Journal of Basic Applied Sciences Research, 4(3), 224-231.

Ashaduzzaman, M., \& Asif-Ur-Rahman, S. M. (2011). Impact of Television Advertisements on buying pattern of Women in Dhaka City. European Journal of Business and Management, 3(3), 16-27. 
Azeem, A., \& Haq, Z. U. (2012). Perception towards Internet advertising: A study with reference to three different demographic groups. Global Business and Management Research: An International Journal, 4(1), 28-45.

Barroso, A. \& Llobet, G. (2011). Advertising and Consumer Awareness of New, Differentiated Products, CEMFI Working Paper No. 1104

Barroso, A. (2008). Advertising and Consumer Awareness of a New Product

Bhutto, R. A., \& Maqsood, A. Customer Services: A Case Study of Cellular Phone Companies in Pakistan.

Chakrabortty, R. K., Hossain, M. M., Farhad, M., Azad, H., \& Islam, M. J. (2013). Analyzing the Effects of Sales Promotion and Advertising on consumer's Purchase Behaviour, World Journal of Social Sciences 3(4), 183 - 194

Chowdhury, H. K., Parvin, N., Weitenberner, C., \& Becker, M. (2006). Consumer attitude toward mobile advertising in an emerging market: An empirical study. International Journal of Mobile Marketing, 1(2).Okeleke, K., Rogers, M., \& Pedros, X. (2017). The Mobile Economy 2017.

Hassan, A. (2015). Effects of TV Advertisement on Consumer Buying Behaviour: A Comparative Study of Rural-Urban and Male-Female Consumers. International Journal of Innovation and Applied Studies, 11(3), 608.

Honkaniemi, M. (2014). Consumer' s product perceptions and the impact of advertising on product images: case Mieleinen honey product.

MacInnis, D. J., Moorman, C., \& Jaworski, B. J. (1991). Enhancing and measuring consumers' motivation, opportunity, and ability to process brand information from ads. The Journal of Marketing, 32-53.

Kahn, E. B. (2014). Glossary, Knowledge Wharton High School, Wharton University Pennsylvania, retrieved on December 22, 2014 and available at http://kwhs.wharton.upenn.edu/term/consumer-choice/

Karim, L.N., Shehzad, M., Arshad, S. (2017). Effects of TV Advertising of Cellular Companies on User's Behavior. International Journal of Humanities and Social Science, $7(3)$

Malik, M. E., Ghafoor, M. M., \& Iqbal, H. K. (2014). The Impact of Advertisement and Consumer Perception on Consumer Buying Behavior. International Review of Social Sciences \& Humanities, 6(2).

Rossiter, J. R., \& Percy, L. (1987). Advertising and promotion management. McGrawHill Book Company. 
Saeed, R., Zameer, H., \& Abbas, R. (2012). Mobile Phone buying behavior of consumers; A comparative study of Rural and Urban consumers in Pakistan. Global Journal of Management and Business Research, 12(6).

Saleem, S., \& Abideen, Z. (2011). Effective advertising and its influence on consumer buying behavior. European Journal of Business and Management, 3(3), 55-67.

Sawant, R. P. (2012). Impact of Advertising on Brand Awareness and Consumer Preference (With Special Reference to Men's Wear). IOSR Journal of Business and Management, 5(6), 54-61.

Topaloğlu, G. (2012). Consumer motivation and concern factors for online shopping in turkey, Asian Academy of Management Journal, 17(2) 1-19 